\title{
Distribution patterns in the biomass of macrozoobenthic communities in Admiralty Bay (King George Island, South Shetlands, Antarctic)
}

\author{
Krzysztof Pabis • Jacek Sicinski • \\ Magdalena Krymarys
}

Received: 5 March 2010/Revised: 6 October 2010/Accepted: 7 October 2010/Published online: 27 October 2010

(C) The Author(s) 2010. This article is published with open access at Springerlink.com

\begin{abstract}
The distribution patterns of macrozoobenthic communities as shown by the biomass of the higher taxa were investigated in Admiralty Bay. Material was collected at depths ranging from 4 to $500 \mathrm{~m}$ (102 quantitative samples), representing the full depth range of this basin and including areas characterized by the different levels of glacial influence. Five community groups were distinguished by multivariate analysis (clustering, MDS) based on the Bray-Curtis similarity index. In the Ezcurra Inlet, the area characterized by intensive glacial processes resulting in a high sedimentation rate, the distribution of biomass was not depth related, but was associated with the intensity of glacial disturbance along the axis of the fjord. The innermost part of this fjord, which receives strong outflows from glaciers, had a low biomass value $(2.9 \mathrm{~g} /$ $0.1 \mathrm{~m}^{2}$ ) and was dominated by polychaetes. The middle part of the fjord which is not so heavily disturbed had higher biomass values $\left(46.1 \mathrm{~g} / 0.1 \mathrm{~m}^{2}\right)$ due to the dominance of bivalves. A clear depth gradient of biomass distribution was observed in bottom areas located far from glaciers, in the central basin of the bay, with three zones within the depth ranges 4-30, 40-380, and 400-500 m. The highest mean biomass values $\left(92.5 \mathrm{~g} / 0.1 \mathrm{~m}^{2}\right)$ were found in the middle sublittoral $(40-380 \mathrm{~m})$ dominated by ascidians. In the shallow and deep assemblages, the biomass was lower $\left(33.8 \mathrm{~g} / 0.1\right.$ and $30.9 \mathrm{~g} / 0.1 \mathrm{~m}^{2}$
\end{abstract}

\footnotetext{
K. Pabis $(\bowtie) \cdot$ J. Sicinski $\cdot$ M. Krymarys

Laboratory of Polar Biology and Oceanobiology,

University of Lodz, Banacha 12/16, 90-237 Lodz, Poland

e-mail: cataclysta@wp.pl

J. Sicinski

e-mail: sicinski@biol.uni.lodz.pl

M. Krymarys

e-mail: mkrymarys@gmail.com
}

respectively), most probably associated with the ice disturbance in the shallows and lower food supply in the deepest part of the shelf.

Keywords West Antarctic - Macrozoobenthos · Distribution patterns · Glacial fjord

\section{Introduction}

Antarctic benthic biomass is considered to be relatively high compared to that of other regions of the world. It is only in the shallow water areas from the intertidal to $10 \mathrm{~m}$ depth, often disturbed by glacial processes, that there is no difference between Antarctic and non-Antarctic sites (Brey and Gerdes 1997). Antarctic benthic shelf assemblages have a biomass comparable to those of the most productive regions of the world's ocean (Knox 1994). On the other hand, it was pointed out by Gutt (1991) that this Antarctic habitat is also characterized by a wide range of variation in that biomass.

The main groups of macroinvertebrates that contribute to the high biomass values on Antarctic shelf are sponges, echinoderms, ascidians, and bryozoans (Brey and Gerdes 1997). These epifaunal, suspension-feeding communities have a patchy distribution and are among the most important routes of energy transfer from the pelagial to the benthic zone in the Southern Ocean (Gili et al. 2001). Another important feature of the Antarctic benthos distribution is that these assemblages are not uniform in their trophic structure. Two most important feeding modes, suspension-feeding and deposit-feeding, are distributed within different depth ranges, and the bathymetric segregation observed in these two groups also results in the segregation of biomass values (Saiz-Salinas et al. 1997, 1998). The biomass of the suspension-feeding epifauna is 
probably one or two orders of magnitude larger than the biomass of the infauna (Gallardo 1987; Knox 1994).

Estimations of biomass have been presented for several Antarctic locations, including the South Orkney Islands (White and Robins 1972), Syowa Station (Numanami et al. 1986), Terra Nova Bay (Gambi et al. 1994), Adelaide Island (Barnes and Brockington 2003), and Victoria Land on the Ross Sea (Rehm et al. 2006), but multivariate analysis of biomass data has been used only rarely (SaizSalinas et al. 1997). Biomass analyses have also been performed for the South Shetland Islands (Saiz-Salinas et al. 1997, 1998; Arnaud et al. 1998; Saiz-Salinas and Ramos 1999; Piepenburg et al. 2002). The biomass of benthic macrofaunal communities in Admiralty Bay was studied by Jazdzewski et al. (1986) but the analysis was based only on three transects within 15-250 m depth range.

There is still a relatively small number of studies on Antarctic benthic biomass distribution compared to those based on abundance data, and for most of these studies, there are no data from the full depth range of the shelf, and the number of samples is often very limited. Further, the gradients associated with glacial processes are still rarely analyzed in the Antarctic compared to the Arctic (WlodarskaKowalczuk et al. 2005; Smale and Barnes 2008). This is an important problem in the context of global climate change and the warming observed in the Antarctic Peninsula region, as the intensity of those processes will most probably increase during the next century resulting in changes in marine benthic communities (Barnes and Peck 2008; Smale and Barnes 2008). Admiralty Bay is a very appropriate site for such research as a basin with many glacially influenced parts of the coast as well as places located far from glaciers (Braun and Grossmann 2002), and with extensive background knowledge on the environmental factors like meltwater influence, inorganic sedimentation inflow, water turbidity, and sediment type (Pecherzewski 1980; Szafranski and Lipski 1982; Jonasz 1983; Lipski 1987; RakusaSuszczewski 1995; Sicinski 2004).

The aim of the present study was to determine the patterns of macrozoobenthic biomass distribution in the whole depth range of Admiralty Bay (from 4 to $500 \mathrm{~m}$ ), as well as ranging from areas with strong glacial activity to the open waters of the central basin in areas located far from glaciers.

\section{Materials and methods}

Study area

Admiralty Bay is a fjord-like embayment which consists of a central basin and three inlets: Ezcurra Inlet, Martel Inlet, and MacKellar Inlet. Ezcurra Inlet is a typical narrow fjord with shores covered with glaciers and with strong meltwater influence (Pecherzewski 1980; Braun and Grossmann 2002). The largest glaciers are located in the innermost part of this fjord while the outer part have almost glacier-free coastline (Fig. 1).

On the seafloor of Ezcurra Inlet, two main areas can be distinguished. The youngest, shallower inner part of the fjord has an intricate bottom configuration. The older part, in the outer fjord area, forms a deep trough. These two parts are separated by a sill, which has a great influence on the distribution of benthic communities (Marsz 1983; Sicinski 2004). The deepest part of Ezcurra Inlet is located in its outer part and reaches about $270 \mathrm{~m}$.

The central basin is the deepest part of the Admiralty Bay reaching $550 \mathrm{~m}$, and it is open to the Bransfield Strait. Glacier cover on the shores of the central basin is
Fig. 1 Distribution of samples from five distinguished groups in Ezcurra Inlet and central basin of Admiralty Bay

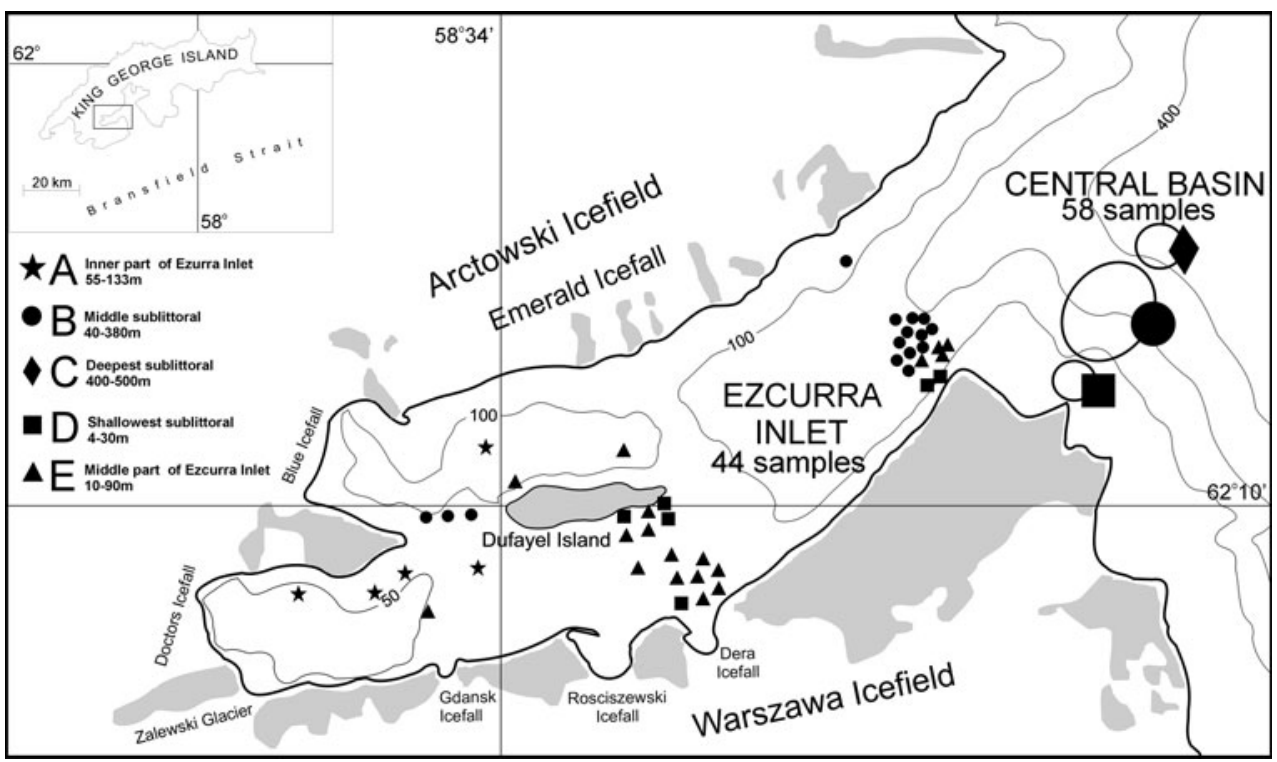


distributed mainly along the eastern coast, and it is not present in the area located at the edge of its western coast and coast of Ezcurra (Braun and Grossmann 2002). Also, the sedimentation rates are different in Ezcurra Inlet and in the central basin of the bay. High amounts of mineral suspended matter $\left(>100 \mathrm{mg} / \mathrm{dm}^{3}\right)$ were recorded during summer in front of the glacier cliffs. The lowest values $\left(2.8 \mathrm{mg} / \mathrm{dm}^{3}\right)$ were observed in winter, in the central part of the bay (Pecherzewski 1980).

\section{Sampling}

Most of the samples were collected using a van Veen grab $\left(0.1 \mathrm{~m}^{2}\right)$ including 44 samples from Ezurra Inlet and 50 samples from the central basin, taken in the summer seasons of 1979/1980, 1984/1985, and 1985/1986. Another eight samples from the shallowest sublittoral of the central basin were collected with a Tvärminne Kangas sampler $\left(565 \mathrm{~cm}^{2}\right)$ in the summer season of 1988 . Biomass values from those eight samples were converted to $0.1 \mathrm{~m}^{2}$ surface area. The samples were sieved on a $0.5-\mathrm{mm}$ mesh sieve. The samples covered the whole depth range of Admiralty Bay from 4 to $500 \mathrm{~m}$ depth and were distributed in a gradient from the disturbed inner parts of Ezcurra Inlet to the open, deepest sublittoral of the central basin (Fig. 1).

\section{Data analysis}

Samples were identified to thirty-eight higher taxa (Table 1). The family Siboglinidae (formerly Pogonophora) was treated separately from other polychaetes because of their unique features (no mouth, a symbiotic relationship with chemoautotrophic bacteria). Biomass for each taxon was measured to the nearest $\mathrm{mg}$ as blotted wet weight.

The similarities between samples were calculated using the Bray-Curtis similarity index. Hierarchical agglomerative clustering was performed using the group average method. Nonmetric multidimensional scaling (MDS) was used for sample ordination. The data matrix of macrozoobenthos higher taxa biomass values (wet weight in $\mathrm{mg}$ / $0.1 \mathrm{~m}^{2}$ ) were $\log _{10}$ transformed (Clarke and Warwick 1994).

Differences between the total biomass values in the distinguished groups were tested with the use of the nonparametric Kruskal-Wallis test and post hoc multiple comparisons using the STATISTICA 6 package.

\section{Results}

Five groups of samples were distinguished in the cluster analysis (Fig. 2). Similar trends were found on the MDS plot (Fig. 3). These five clusters represent five areas of the Admiralty Bay bottom with distinct depth ranges and distribution in the bay (Fig. 1) as well as with different proportions of particular invertebrate taxa biomass in each group (Fig. 4). Total biomass values were significantly different between some groups $(\mathrm{A} / \mathrm{B}, \mathrm{A} / \mathrm{D}, \mathrm{A} / \mathrm{E}, \mathrm{B} / \mathrm{C}, \mathrm{B} / \mathrm{D}$, and $\mathrm{B} / \mathrm{E})(P<0.01)$. No significant differences were found between the pairs $\mathrm{A} / \mathrm{C}, \mathrm{C} / \mathrm{D}, \mathrm{C} / \mathrm{E}$, and $\mathrm{D} / \mathrm{E}$. Cluster and MDS analysis clearly separated some areas of Ezcurra Inlet from the central basin areas on similar depths (Figs. 1, 2, 3).

\section{Group A}

Group A contains samples from the innermost part of Ezcurra Inlet, behind the Dufayel Island (55-133 m depth) (Fig. 1). This group was separated from other assemblages in the first, most general division of the dendrogram (Fig. 2). The bottom fauna of this area was very poor with only 12 taxa recorded (Table 1) and had a very low mean biomass of $2.9 \mathrm{~g} / 0.1 \mathrm{~m}^{2}$. The most important group in terms of biomass was Polychaeta with almost 75\% dominance (Fig. 4).

\section{Group B}

Group B contains the samples from the middle sublittoral of Admiralty Bay, from the central basin and the outer part of Ezcurra Inlet (40-380 m) (Fig. 1). This group had the highest value of mean biomass $\left(92.5 \mathrm{~g} / 0.1 \mathrm{~m}^{2}\right)$. Almost all analyzed taxa were found in this bottom area (Table 1). Large colonial suspension feeders (Ascidiacea, Bryozoa, and Porifera) were very important components of the biomass (together almost $70 \%$ of biomass), followed by Polychaeta with almost $17 \%$ of biomass (Fig. 4).

\section{Group C}

This very distinct group represented the deepest sublittoral of Admiralty Bay (400-500 m). The most important taxon was Polychaeta (39\%) but this is the only cluster with the large amount of Echiura (29\%) and Anthozoa (17\%) (Fig. 4; Table 1). The mean value of total biomass was $30.9 \mathrm{~g} / 0.1 \mathrm{~m}^{2}$.

\section{Group D}

This cluster grouped the samples from the shallowest sublittoral (4-30 m) distributed mostly in the central basin, with some samples from outer part of Ezcurra Inlet and from steep slopes of Dufayel Island. It was a very distinct group with Echinoidea, Bivalvia, and Asteroidea as the most important taxa (Fig. 4). The mean value of biomass was $33.8 \mathrm{~g} / 0.1 \mathrm{~m}^{2}$. Extremely low mean polychaete biomass $\left(2 \mathrm{~g} / 0.1 \mathrm{~m}^{2}\right)$ was observed here. Conversely, amphipod and isopod mean biomass values were the highest in the whole investigated bottom area, 1.7 and $1.2 \mathrm{~g} / 0.1 \mathrm{~m}^{2}$, 
Table 1 Mean biomass values $\left[\mathrm{g} / 0.1 \mathrm{~m}^{2}\right.$ ] with standard deviation (SD) in every assemblage and in the whole study area (All)

\begin{tabular}{|c|c|c|c|c|c|c|c|c|c|c|c|c|}
\hline \multirow[t]{2}{*}{ Taxa } & \multicolumn{2}{|l|}{ A } & \multicolumn{2}{|l|}{ B } & \multicolumn{2}{|l|}{$\mathrm{C}$} & \multicolumn{2}{|l|}{$\mathrm{D}$} & \multicolumn{2}{|l|}{ E } & \multicolumn{2}{|l|}{ All } \\
\hline & Mean & SD & Mean & SD & Mean & SD & Mean & SD & Mean & SD & Mean & SD \\
\hline Ascidiacea & - & - & 52.3 & 85.3 & 0.3 & 0.5 & 0.007 & 0.03 & 0.01 & 0.04 & 28.2 & 67.6 \\
\hline Polychaeta & 2.2 & 4.3 & 15.5 & 9.5 & 12.3 & 7.2 & 2.0 & 1.6 & 2.2 & 2.4 & 9.9 & 9.7 \\
\hline Bivalvia & 0.09 & 0.2 & 1.1 & 2.1 & 0.2 & 0.2 & 6.5 & 8.9 & 36.0 & 92.0 & 8.1 & 40.2 \\
\hline Bryozoa & 0.004 & 0.008 & 8.4 & 15.2 & 0.07 & 0.2 & 0.3 & 1.2 & 0.01 & 0.03 & 4.6 & 11.9 \\
\hline Ophiuroidea & - & - & 6.3 & 7.6 & 0.2 & 0.2 & 0.0006 & 0.002 & 5.0 & 9.8 & 4.3 & 7.4 \\
\hline Echinoidea & - & - & 2.8 & 8.1 & 0.005 & 0.01 & 12.4 & 27.35 & 0.5 & 2.2 & 3.8 & 13.4 \\
\hline Porifera & - & - & 2.4 & 15.7 & 0.3 & 0.8 & - & - & 0.9 & 2.1 & 1.5 & 11.6 \\
\hline Nemertina & 0.0007 & 0.001 & 0.2 & 1.3 & 1.9 & 4.4 & 4.2 & 13.2 & 0.02 & 0.06 & 1.0 & 5.8 \\
\hline Asteroidea & 0.5 & 1.1 & 0.04 & 0.1 & - & - & 4.8 & 19.8 & 0.02 & 0.09 & 0.9 & 8.3 \\
\hline Anthozoa & - & - & 0.5 & 1.3 & 5.3 & 8.1 & 0.0008 & 0.003 & 0.4 & 1.3 & 0.6 & 2.4 \\
\hline Echiura & - & - & 0.1 & 1.1 & 9.1 & 11.1 & - & - & - & - & 0.6 & 3.3 \\
\hline Gastropoda & - & - & 0.6 & 2.8 & - & - & 0.2 & 0.6 & 0.2 & 0.9 & 0.4 & 2.1 \\
\hline Amphipoda & 0.1 & 0.04 & 0.2 & 0.2 & 0.1 & 0.2 & 1.7 & 2.4 & 0.1 & 0.09 & 0.4 & 1.1 \\
\hline Holothuroidea & - & - & 0.7 & 2.4 & 0.01 & 0.01 & 0.03 & 0.01 & - & - & 0.4 & 1.8 \\
\hline Isopoda & 0.0001 & 0.0002 & 0.06 & 0.1 & 0.5 & 1.0 & 1.2 & 3.0 & 0.0009 & 0.002 & 0.3 & 1.3 \\
\hline Sipuncula & - & - & 0.2 & 1.7 & 0.03 & 0.007 & 0.00003 & 0.0001 & - & - & 0.1 & 1.3 \\
\hline Priapulida & - & - & 0.1 & 1.2 & 0.002 & 0.003 & 0.02 & 0.06 & 0.03 & 0.09 & 0.1 & 0.8 \\
\hline Crinoidea & - & - & 0.2 & 1.1 & - & - & 0.005 & 0.02 & 0.003 & 0.01 & 0.1 & 0.8 \\
\hline Hydrozoa & - & - & 0.2 & 0.8 & 0.04 & 0.05 & 0.00003 & 0.0001 & 0.0005 & 0.002 & 0.1 & 0.6 \\
\hline Oligochaeta & 0.006 & 0.007 & 0.07 & 0.1 & 0.02 & 0.01 & 0.05 & 0.067 & 0.02 & 0.02 & 0.05 & 0.1 \\
\hline Brachiopoda & - & - & 0.0003 & 0.002 & - & - & - & - & 0.2 & 1.1 & 0.04 & 0.4 \\
\hline Pycnogonida & - & - & 0.05 & 0.08 & 0.2 & 0.1 & 0.00003 & 0.0001 & - & - & 0.04 & 0.08 \\
\hline Polyplacophora & - & - & 0.01 & 0.09 & - & - & 0.1 & 0.4 & - & - & 0.03 & 0.2 \\
\hline Cumacea & 0.002 & 0.003 & 0.01 & 0.02 & 0.0007 & 0.001 & 0.01 & 0.04 & 0.1 & 0.2 & 0.03 & 0.08 \\
\hline Decapoda & - & - & 0.04 & 0.3 & 0.00003 & 0.00008 & - & - & - & - & 0.02 & 0.2 \\
\hline Siboglinidae & - & - & 0.006 & 0.04 & 0.1 & 0.2 & - & - & 0.02 & 0.1 & 0.01 & 0.07 \\
\hline Scaphopoda & - & - & 0.01 & 0.03 & 0.07 & 0.07 & - & - & 0.01 & 0.03 & 0.01 & 0.3 \\
\hline Tanaidacea & 0.0004 & 0.0009 & 0.008 & 0.01 & 0.01 & 0.01 & 0.01 & 0.04 & 0.0006 & 0.0008 & 0.008 & 0.02 \\
\hline Ostracoda & - & - & 0.008 & 0.007 & 0.01 & 0.01 & 0.003 & 0.004 & 0.004 & 0.008 & 0.006 & 0.008 \\
\hline Hirudinea & - & - & 0.005 & 0.02 & & & 0.0002 & 0.0009 & 0.0002 & 0.0007 & 0.003 & 0.2 \\
\hline Nematoda & 0.0002 & 0.0004 & 0.003 & 0.006 & 0.001 & 0.002 & 0.001 & 0.001 & 0.001 & 0.002 & 0.002 & 0.004 \\
\hline Entoprocta & - & - & 0.003 & 0.009 & - & - & - & - & 0.002 & 0.01 & 0.002 & 0.008 \\
\hline Leptostraca & - & - & 0.003 & 0.009 & 0.0003 & 0.0005 & - & - & - & - & 0.001 & 0.007 \\
\hline Foraminifera & - & - & 0.002 & 0.003 & - & - & 0.0001 & 0.0002 & - & - & 0.001 & 0.003 \\
\hline Solenogastres & - & - & - & - & - & - & 0.004 & 0.02 & - & - & 0.0008 & 0.008 \\
\hline Copepoda & 0.0002 & 0.0003 & 0.0005 & 0.001 & 0.0001 & 0.0004 & 0.0002 & 0.0005 & - & - & 0.0003 & 0.001 \\
\hline Acarina & - & - & 0.0001 & 0.0003 & - & - & - & - & - & - & 0.00005 & 0.002 \\
\hline Turbellaria & - & - & - & - & - & - & 0.0002 & 0.0009 & - & - & 0.00004 & 0.0004 \\
\hline
\end{tabular}

respectively. A relatively high biomass of Tanaidacea was also a peculiar feature of this assemblage (Table 1).

\section{Group E}

This cluster mostly grouped the samples from the middle part of Ezcurra Inlet, close to Dufayel Island, with single samples from the outer part of this fjord (Fig. 1). It has the second largest mean biomass value $\left(46.1 \mathrm{~g} / 0.1 \mathrm{~m}^{2}\right)$ after the Group B. It was characterized by a high biomass of Bivalvia (almost $80 \%$ and mean value $36.0 \mathrm{~g} / 0.1 \mathrm{~m}^{2}$ ) with a distinct ratio of Ophiuroidea and Polychaeta (Fig. 4; Table 1).

Thirty-eight higher taxa were found and included in the analysis (Table 1). The highest mean values of biomass recorded for the whole study area were found for 
Fig. 2 Dendrogram of samples for the Bray-Curtis similarity based on biomass values, $\log _{10}$-transformed data, and group average grouping method. $C B$ central basin, EZ Ezcurra Inlet

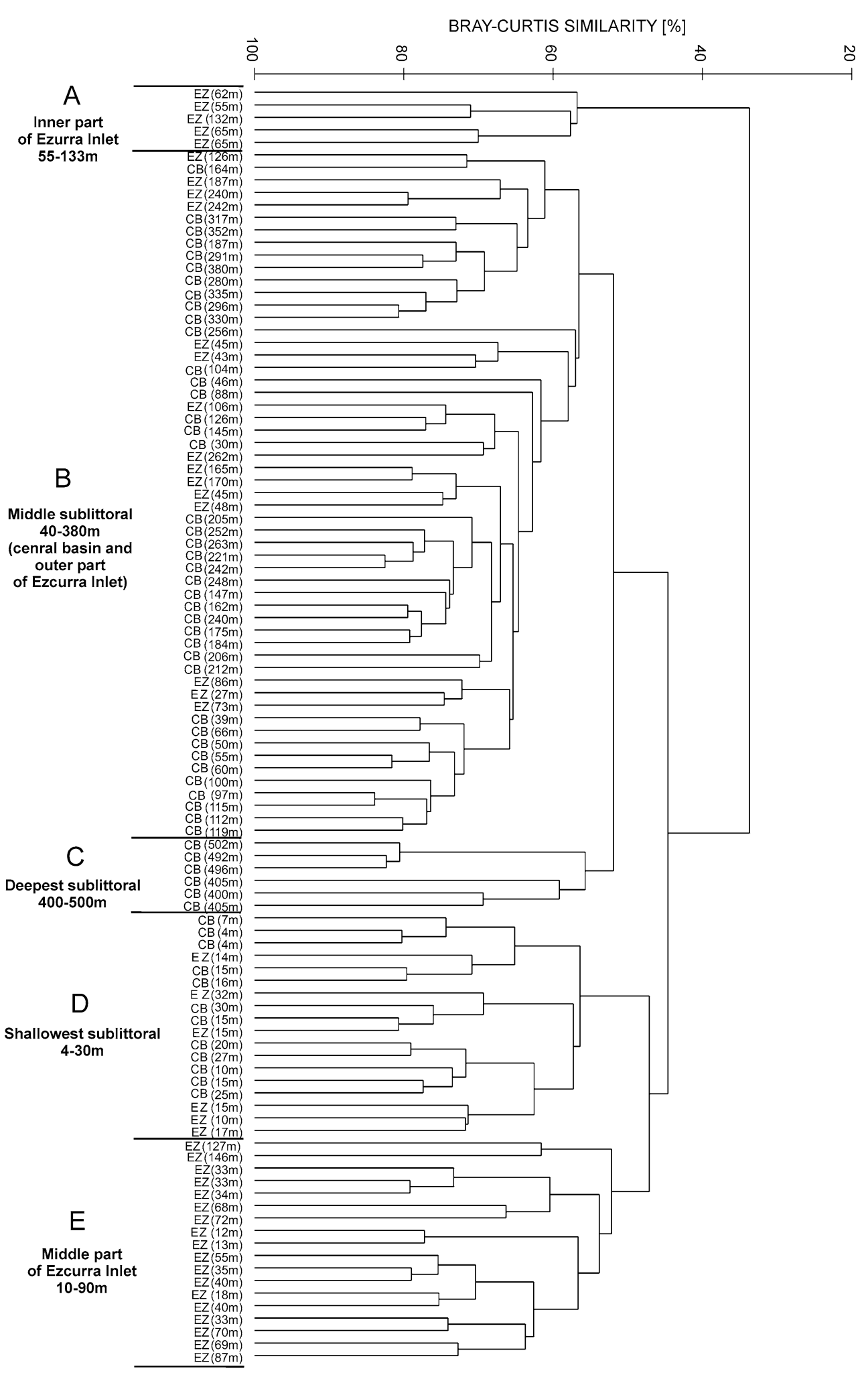

Ascidiacea $\left(28.2 \mathrm{~g} / 0.1 \mathrm{~m}^{2}\right)$, Polychaeta $\left(9.9 \mathrm{~g} / 0.1 \mathrm{~m}^{2}\right)$, and Bivalvia $\left(8.1 \mathrm{~g} / 0.1 \mathrm{~m}^{2}\right)$. Maximal values of biomass recorded for colonial epifauna were much higher (Ascidiacea $320 \mathrm{~g} / 0.1 \mathrm{~m}^{2}$, Bryozoa $93 \mathrm{~g} / 0.1 \mathrm{~m}^{2}$ ) than for infauna
(Polychaeta $60 \mathrm{~g} / 0.1 \mathrm{~m}^{2}$ ). Mean macrozoobenthos biomass recorded for the whole study area was $66 \mathrm{~g} / 0.1 \mathrm{~m}^{2}$. The minimum recorded biomass value was $0.1 \mathrm{~g} / 0.1 \mathrm{~m}^{2}$, and the maximum value was $392 \mathrm{~g} / 0.1 \mathrm{~m}^{2}$. 
Fig. 3 MDS plot for the Bray-Curtis similarity based on biomass values, $\log _{10}$-transformed data

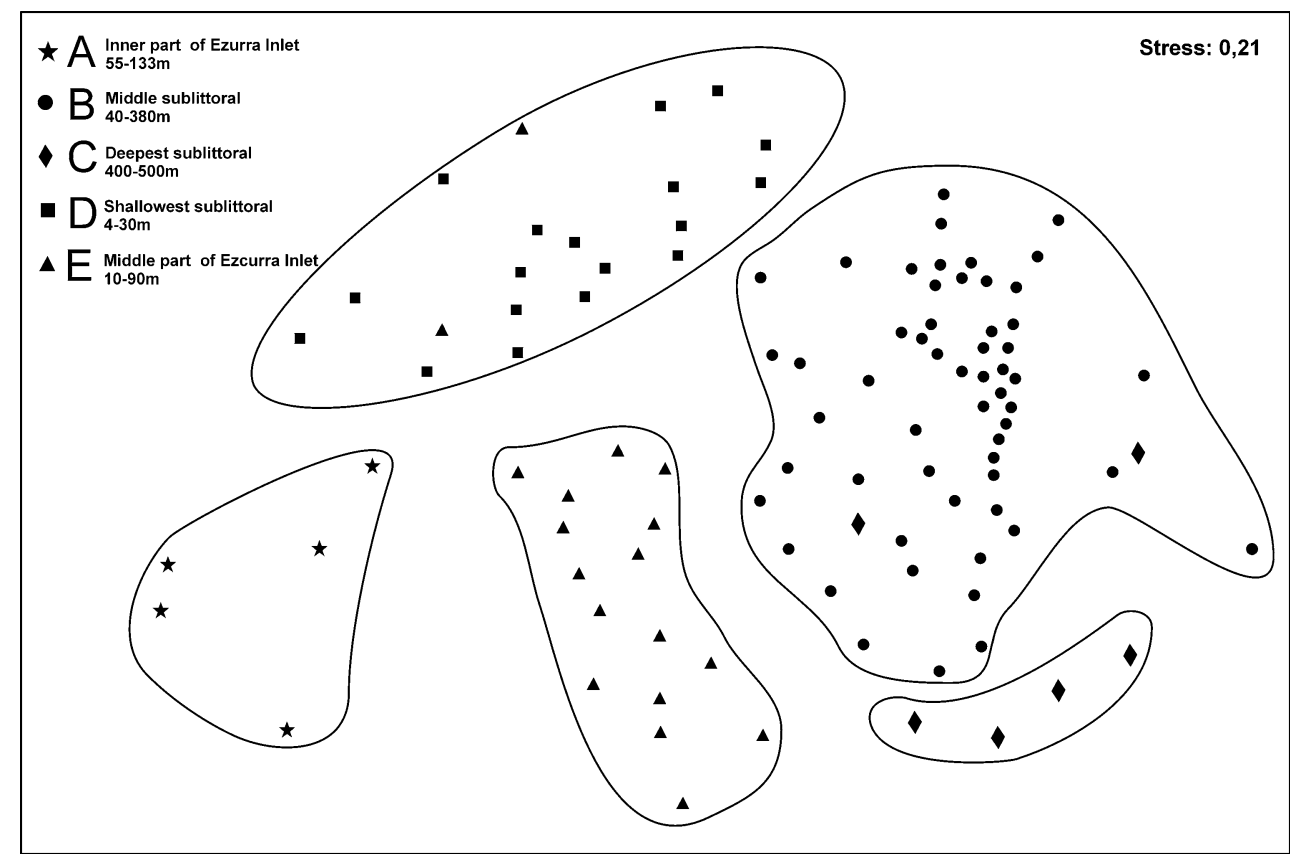

Fig. 4 Biomass proportions [\%] in the distinguished assemblages with mean total biomass values $\left[\mathrm{g} / 0.1 \mathrm{~m}^{2}\right]$ and standard deviations (SD) (size of the circles represents the proportion between mean biomass value for each assemblage)

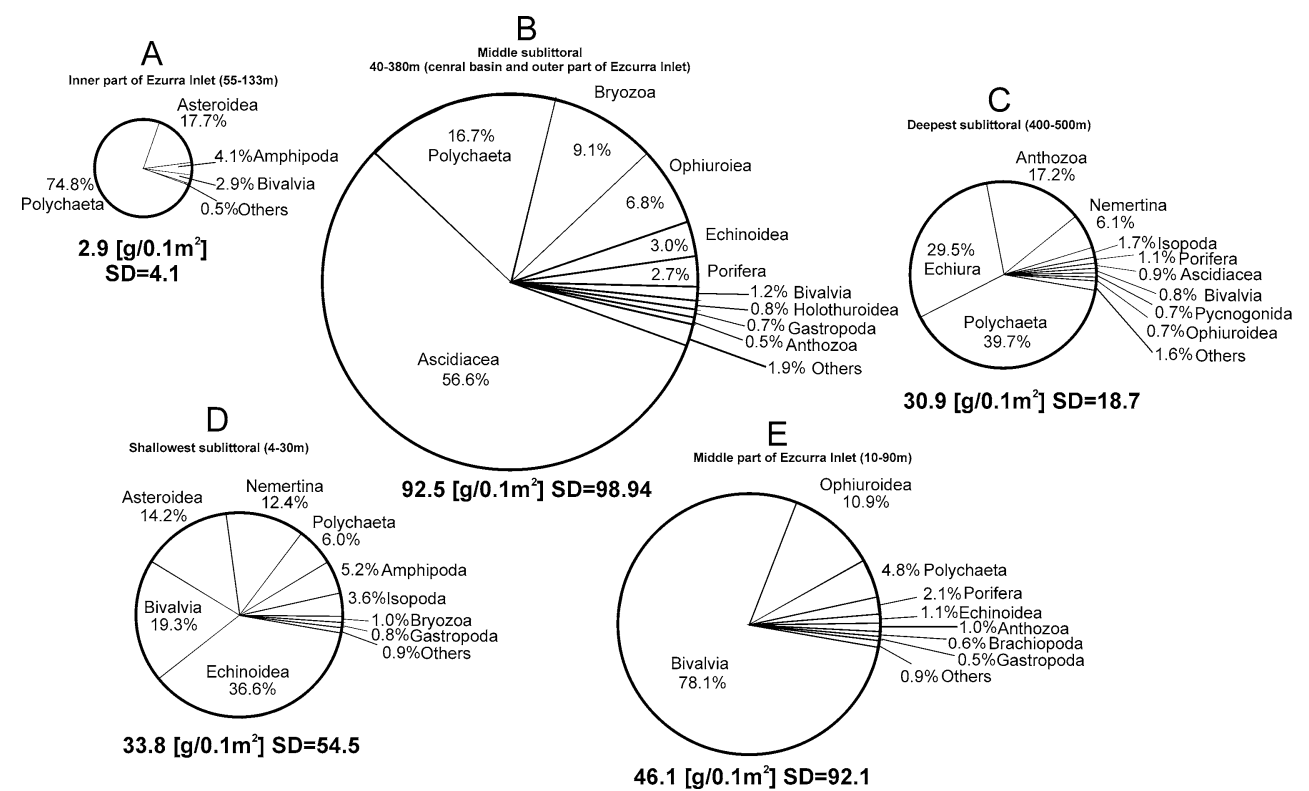

Some other distinct features of biomass distribution were also observed. In the central basin of the bay, a clear pattern of biomass distribution along the depth gradient can be seen (Figs. 2, 3, 5a). Conversely, in the Ezcurra Inlet, the distribution of biomass was not related to depth (Figs. 1, 2, 3, 5b). It was confirmed in the distribution of particular taxa (Fig. 6). Only Bivalvia and Polychaeta displayed some similar trends in their distribution along the depth gradient of Ezcurra Inlet and along the depth gradient of the central basin. However, biomass of Bivalvia in Ezcurra Inlet was much higher than in the central basin. Of further differences between biomass values of specific taxa in those two parts of Admiralty Bay, Bryozoa were one of the most important groups in the central basin, but almost absent in Ezcurra Inlet, and the biomass of Amphipoda in the Ezcurra Inlet was lower than in the central basin and did not exceed $1 \mathrm{~g} / 0.1 \mathrm{~m}^{2}$.

\section{Discussion}

According to Saiz-Salinas et al. (1997), depth is the most important factor structuring Antarctic macrozoobenthic biomass. A similar tendency in decrease in biomass 
Fig. 5 Distribution of total macrozoobenthos biomass in samples $\left[\mathrm{g} / 0.1 \mathrm{~m}^{2}\right]$ along the depth gradient of central basin and Ezcurra Inlet
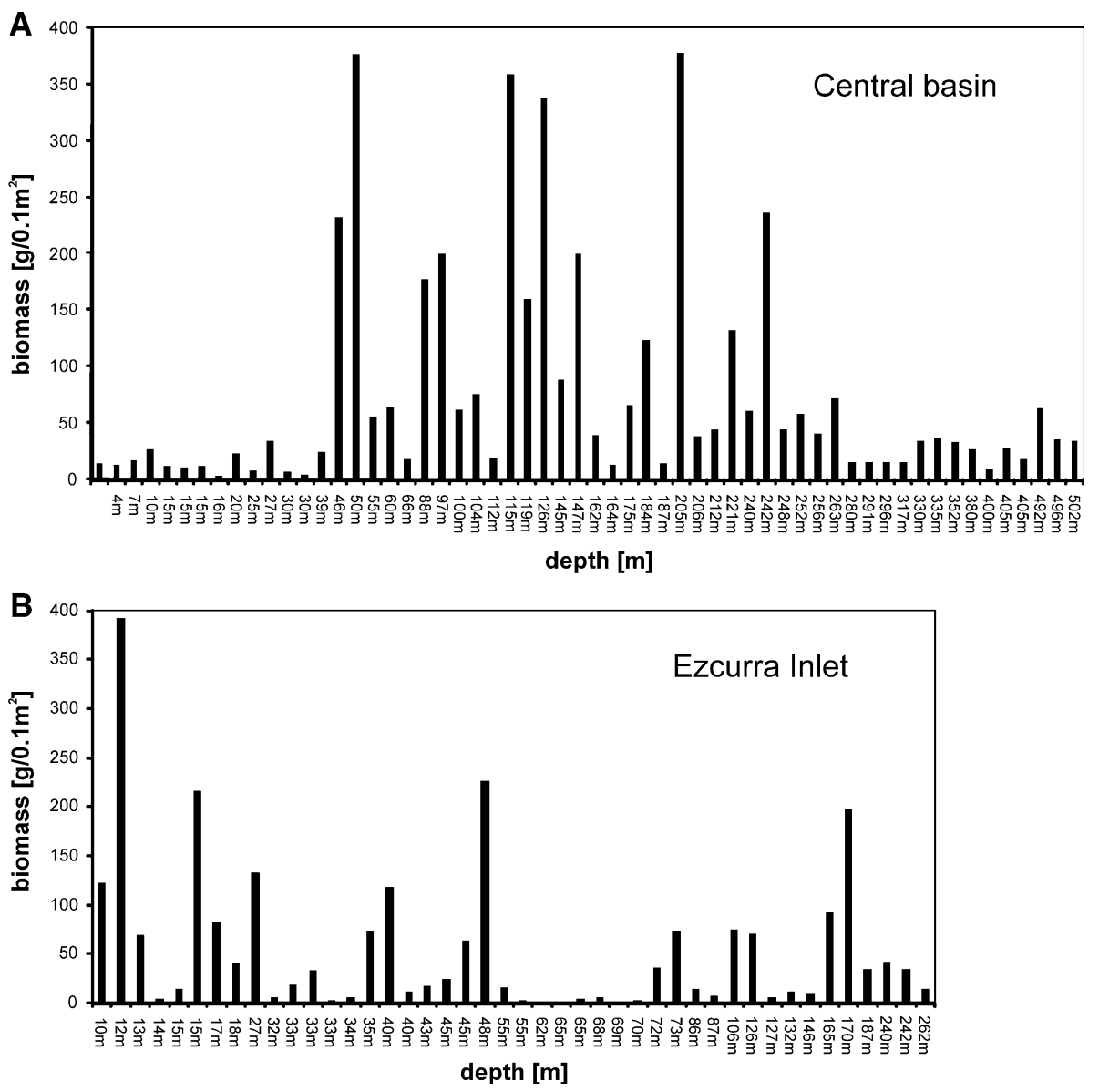

values with increasing depth was observed in the Ross Sea (Rehm et al. 2006). According to the results from Admiralty Bay, depth is important for the distribution of macrozoobenthos and biomass values especially in areas that are not so heavily influenced by glaciers as found in the central basin. In this part of the bay, distinct depth gradient is shown with lower biomass in the shallows (4-30 m), high biomass values in the middle sublittoral $(40-380 \mathrm{~m})$ and again a decrease in biomass values in the deepest part of the shelf $(400-500 \mathrm{~m})$. In the shallow areas, direct ice impact can be the most important factor influencing the macrobenthic communities and the reason for low biomass (Brey and Gerdes 1997; Gutt 2001). At greater depths, the decrease in biomass and the absence of large epifaunal suspension feeders like Bryozoa and Ascidiacea is most probably associated with lower values of particulate organic matter content (Saiz-Salinas et al. 1997; Saiz-Salinas et al. 1998). It is also interesting that while the taxonomic compositions of the shallow water assemblage (Group D 4-30 m) and deepest sublittoral assemblage (Group C 400-500 m) were completely different, there was no significant difference between the total biomass values in those two areas of Admiralty Bay.
Saiz-Salinas et al. (1997, 1998) pointed out that in Antarctic benthic communities, a distinct segregation of two feeding modes (epifaunal suspension feeders and infaunal deposit feeders) can be observed. This segregation could be associated with quantity and quality of suspended organic matter along the depth gradient, with higher nutrient supply in the shallows compared to the deeper parts of the shelf. In the study from Livingston Island, Deception Island, and Bransfield Strait, these two major zones were separated at $100 \mathrm{~m}$ depth. Ascidiacea and Porifera were the most important biomass component at shallower depths, while Polychaeta was the most important taxon in the deeper part of the shelf. Similar observations with a dominance of suspension feeders (Ascidiacea, Porifera, Bryozoa) below $130 \mathrm{~m}$ depth but with a variety of trophic strategies (with Ophiuroidea, Asteroidea, and Polychaeta as the main groups) at deeper sites were found by Arnaud et al. (1998) on Livingston Island. However, in Admiralty Bay, Polychaeta were an important component of the biomass in almost all distinguished groups. There was not a segregation of the two feeding modes but rather a zonation of the presence of suspension feeders (Ascidiacea, Bryozoa, Porifera) with a constant presence of the infaunal component on the whole shelf. Polychaete biomass values 

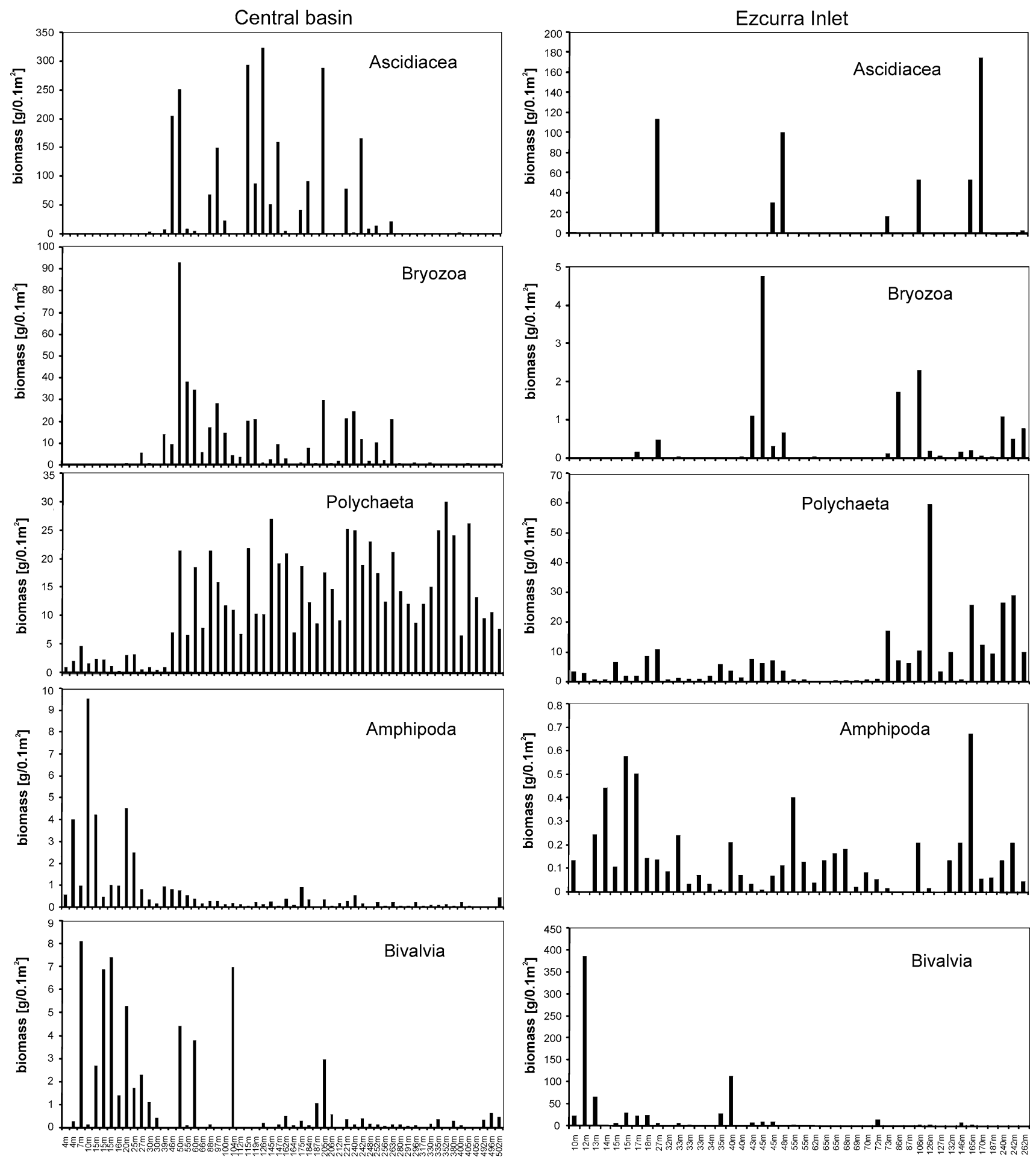

Fig. 6 Distribution of biomass of selected taxa in samples $\left[\mathrm{g} / 0.1 \mathrm{~m}^{2}\right]$ along the depth gradient of central basin and Ezcurra Inlet

were high from $c a 40 \mathrm{~m}$ in the central basin and showed high variation in Ezcurra Inlet (Fig. 6). In the middle sublittoral assemblage (Group B 40-380 m), the mean polychaete biomass reached $15.5 \mathrm{~g} / 0.1 \mathrm{~m}^{2}$. It was the second-ranked taxon after Ascidiacea $\left(52.3 \mathrm{~g} / 0.1 \mathrm{~m}^{2}\right)$, and its biomass values exceeded those found for Bryozoa and
Porifera (Table 1). In a study from the Scotia Arc, polychaetes were also an important component of biomass followed by echinoderms, but most of those samples were taken below $100 \mathrm{~m}$ depth (Mühlenhardt-Siegel 1988).

Saiz-Salinas and Ramos (1999) postulated that there is a natural gradient of benthic assemblages in the Antarctic 
with a dominance of larger invertebrates (mostly filter feeders) in shallower, more nutrient-rich waters and a dominance of smaller invertebrates in the deeper parts of the shelf characterized by a limited supply of organic matter. The relationship between the productivity in the pelagic zone and the biomass of benthic communities is very important (Dayton and Oliver 1977). It is also obvious that suspension feeders can develop greater body sizes than infaunal detritivores associated with a less nutritious source of food. However, Gallardo (1987) pointed out that in the Antarctic, the infauna could be also influenced by filter feeders that reduce the quantity of organic matter during its passage to the bottom.

The efficiency of Antarctic suspension feeders in terms of energy transfer from the pelagial to the benthic zone is very high and comparable to that found in temperate regions. Antarctic suspension-feeding communities have patchy distributions but are very rich, despite the low primary production in the Southern Ocean, this richness being associated with lateral advection and resuspension as well as with the nutritive quality of food (Gili et al. 2001). It is also interesting that assumptions of slower growth of polar invertebrates are not necessarily true. Low temperature and brevity of phytoplankton availability were suggested as reasons of poor secondary productivity in polar regions. But it was confirmed for some bryozoans that their growth rates can increase within increasing latitude in the Antarctic and that it could be associated with reduced interspecific competition (Barnes and Arnold 2001). Antarctic suspension feeders can feed actively even during the winter and are able to exploit even very low food concentrations (Barnes and Clarke 1995).

In the areas like Ezcurra Inlet, depth is not so important because of the strong influence of glaciers (high inorganic suspended matter inflow, salinity, and temperature changes) (Pecherzewski 1980; Szafranski and Lipski 1982) can affect the zoobenthic communities even in the deeper parts of the bottom. That is why the distribution of biomass in this part of Admiralty Bay shows the gradient associated with the intensity of glacial processes, and we can observe the different composition of communities and distinctly lower biomass (Group A and E) than at similar depths in the central basin (Group B). The distribution and character of the assemblages detected in this study correspond with the characteristics of the environmental factors along the axis of Ezcurra Inlet and in the central basin. There was a clear gradient in the suspended matter content in waters of Admiralty Bay. It is visible even at greater depths with high value $(60-100 \mathrm{mg} / \mathrm{l})$ in the innermost part of Ezcurra Inlet, decreasing along the axis of the fjord to very low values $(20-10 \mathrm{mg} / \mathrm{l})$ in the outer part of Ezcurra Inlet and in the central basin (Pecherzewski 1980; Sicinski 2004). Also, water turbidity was high in the Ezcurra Inlet and much lower in the central basin (Lipski 1987). The analysis of sediments at the bottom of Admiralty Bay (Sicinski 2004) showed that innermost parts of Ezcurra Inlet are characterized by clay fractions (silty clay and clay silt) while in the outer part of Ezcurra Inlet and in the central basin, the sediments consist mostly of silty sand and silty clay sand. In front of glacier cliffs in the inlets, high fluctuations of salinity associated with intensive meltwater inflow were observed. The lowest temperatures and salinities were observed close to the glaciers in Ezcurra and MacKellar Inlets (Szafranski and Lipski 1982). Waters of Ezcurra Inlet had also the lowest values of chlorophyll $\alpha$ content (Tokarczyk 1986).

The distribution of assemblages A, E, and B represents the changes in community structure along Ezcurra Inlet from the innermost parts to the outer part and the central basin. The dominance of polychaetes and poverty of the community found in the innermost part of Ezcurra Inlet (Group A) is typical of similar, highly disturbed areas. In the Arctic fjords in similar communities, a high proportion of small eurytopic polychaetes from the families Cirratulidae and/or Spionidae was often found (WlodarkaKowalczuk and Pearson 2004; Wlodarska-Kowalczuk et al. 2005). The high biomass of bivalves in the middle part of Ezcurra Inlet (Group E) is very characteristic of the disturbed polar areas in places with high suspended mineral inflow. Similar trends were observed in many polar locations, especially for members of families: Yoldiidae, Laternulidae, and Thyasiridae (White and Robins 1972; Syvitski et al. 1989; Aitken and Gilbert 1996; WlodarkaKowalczuk and Pearson 2004; Echeverria et al. 2005). These clams are able to live and feed in such conditions (Rhoads 1974). In Admiralty Bay, the most abundant species (also in disturbed parts) are Laternula elliptica, Yoldia eightsi, and Mysella charcoti (Arnaud et al. 1986; Sicinski et al. 1996). These species are very important components of Antarctic benthic communities and are characterized by more intensive growth during the summer season and adaptations to a winter food shortage (Peck et al. 2000; Ahn et al. 2003). The undisturbed assemblage of the outer part of the fjord and the central basin (Group B) was dominated by ascidians and had a very high biomass.

Until now, information about the biomass of the macrozoobenthos in Admiralty Bay had been presented only for a depth range of 15-250 $\mathrm{m}$, on three a priori selected transects (Jazdzewski et al. 1986) and was not studied over the entire depth range or in areas characterized by the different levels of glacial influence. The average biomass value recorded in Admiralty Bay in this study (66 g/ $0.1 \mathrm{~m}^{2}$ ) was similar to the value recorded by Jazdzewski et al. (1986) and to those at other Antarctic locations when compared with data compiled in that paper. The maximal 
values of biomass were, however, higher, with $240 \mathrm{~g} /$ $0.1 \mathrm{~m}^{2}$ recorded by Jazdzewski et al. (1986) and over $390 \mathrm{~g} / 0.1 \mathrm{~m}^{2}$ recorded in this study.

It is interesting that similar patterns of distribution of the higher taxa biomass were observed for the polychaete fauna (mostly epibenthic species) collected by trawling in an analysis based on faunistic similarity (Pabis and Sicinski 2010). Two assemblages were found in the central basin, one in the deepest parts of the bay and one in the middle sublittoral (30-200 m). In Ezcurra Inlet, the distribution of polychaete assemblages showed a mosaic. Similar patterns of distribution were also found in an analysis based on the abundance of infaunal polychaetes, with a mosaic of seven assemblages in Ezcurra Inlet, a clearly distinguished assemblage in the shallowest sublittoral of the Admiralty Bay central basin (7-40 m depth), and the most distinct rich and diverse assemblage in the middle sublittoral of the central basin $(35-150 \mathrm{~m})$, with factors like mineral suspension inflow, distance from glaciers, and sediment type being the most important for the distribution of polychaetes (Sicinski 2004).

It is also interesting that in the group D $(4-30 \mathrm{~m})$, a higher biomass proportion of epibenthic, motile taxa was found. Higher biomass values of Amphipoda in the shallow sublittoral are associated with the high abundance of these crustaceans, reaching up to 17,000 ind. $/ \mathrm{m}^{2}$, in this part of the Admiralty Bay seabed (Jazdzewski et al. 1991). Sterechinus neumayeri is the most common echinoid in Admiralty Bay (Arnaud et al. 1986): in Martel Inlet, it was found in relatively high abundance in the shallow, icedisturbed areas (Nonato et al. 2000), and together with Abatus, it is responsible for the high echinoid biomass values in the shallowest sublittoral of Admiralty Bay. It is a very important species in the Antarctic trophic web, but on the other hand, it is also a slow-growing species that reaches a maximum size at 70 years of age (Brey et al. 1995). It was found as an important biomass component of the shallow Antarctic areas (Propp 1970; Nakajima et al. 1982; Brey et al. 1995; Barnes and Brockington 2003) and is an important species in recolonization processes after the episodes of ice disturbance (Palma et al. 2007).

It has already been suggested that a depth of ca $30 \mathrm{~m}$ is an important zoological boundary for the benthos in the Admiralty Bay soft bottom, which is especially distinct in the central basin of the bay (Jazdzewski and Sicinski 1993; Nonato et al. 2000; Sicinski 2004; Echeverria et al. 2005). Ice scouring is more frequent in the shallow areas and can be one of the factors that reduce biomass values and diversity of benthic communities in the Antarctic down to around $30 \mathrm{~m}$. It can also reduce the availability of places suitable for attachment for sessile species (Echeverria et al. 2005). However, the composition of those shallow water communities can be rebuilt. The recovery of these communities may take many days or, in the case of sessile organisms like sponges, even years and includes mechanisms like locomotion, horizontal migration, and larval recolonization. The undisturbed epifaunal suspensionfeeding communities are probably more than 100 years old (Peck et al. 1999; Gerdes et al. 2003).

\section{Conclusions}

1. In Ezcurra Inlet, the distribution of biomass is not depth related and shows changes associated with different level of glacial influence. It is also characterized by a wide range of variation.

2. A clear depth gradient of biomass distribution can be observed in bottom areas located far from glaciers (western coast of central basin).

3. The biomass of large epifaunal suspension feeders is higher than the biomass of infaunal deposit feeders (mostly Polychaeta) but there is no segregation of these two groups along the depth gradient. Depth zonation was observed for large suspension feeders while the infaunal component was distributed across the whole depth range.

Acknowledgments The study was supported by a grant of the Polish Ministry of Science and Higher Education No 51/N-IPY/2007/ 0 as well as the Census of Antarctic Marine Life project. We also thank three anonymous reviewers for their comments on the manuscript. Special thanks are also due to Roger Bamber for the language corrections.

Open Access This article is distributed under the terms of the Creative Commons Attribution Noncommercial License which permits any noncommercial use, distribution, and reproduction in any medium, provided the original author(s) and source are credited.

\section{References}

Ahn IY, Surh J, Park YG, Kwon H, Choi KS, Kang SH, Choi HJ, Kim KW, Chung H (2003) Growth and seasonal energetic of the Antarctic bivalve Laternula elliptica from King George Island, Antarctica. Mar Ecol Prog Ser 257:99-110

Aitken AE, Gilbert R (1996) Marine Mollusca from Expedition Fjord, Western Axel Heiberg Island, Northwest Territories, Canada. Arctic 49:29-43

Arnaud PM, Jazdzewski K, Presler P, Sicinski J (1986) Preliminary survey of benthic invertebrates collected by Polish Antarctic Expeditions in Admiralty Bay (King George Island, South Shetland Islands, Antarctica). Pol Polar Res 7:7-24

Arnaud PM, Lopez CM, Olaso I, Ramil F, Ramos-Espla AA, Ramos A (1998) Semi-quantitative study of macrobenthic fauna in the region of the South Shetland Islands and the Antarctic Peninsula. Polar Biol 19:160-166

Barnes DKA, Arnold R (2001) A growth cline in encrusting benthos along a latitudinal gradient within Antarctic waters. Mar Ecol Prog Ser 210:85-91 
Barnes DKA, Brockington S (2003) Zoobenthic biodiversity, biomass and abundance at Adelaide Island, Antarctica. Mar Ecol Prog Ser 249:145-155

Barnes DKA, Clarke A (1995) Seasonality of feeding activity in Antarctic suspension feeders. Polar Biol 15:335-340

Barnes DKA, Peck LS (2008) Vulnerability of Antarctic shelf biodiversity to predicted regional warming. Clim Res 37:149163

Braun M, Grossmann H (2002) Glacial changes in the areas of Admiralty Bay and Potter Cove, King George Island, maritime Antarctica. In: Beyer L, Bolter M (eds) Geoecology of the Antarctic ice-free coastal landscapes. Springer, Berlin, pp 75-90

Brey T, Gerdes D (1997) Is Antarctic benthic biomass really higher than elsewhere? Antarct Sci 9:266-267

Brey T, Pearse J, Basch L, McClintock J, Slattery M (1995) Growth and production of Sterechinus neumayeri (Echinoidea: Echinodermata) in McMurdo Sound, Antarctica. Mar Biol 124:279-292

Clarke KR, Warwick RM (1994) Change in marine communities: an approach to statistical analysis and interpretation. Natural Environment Research Council, Plymouth

Dayton PK, Oliver JS (1977) Antarctic soft-bottom benthos in oligotrophic and eutrophic environments. Science 197:55-58

Echeverria CA, Paiva PC, Alves VC (2005) Composition and biomass of shallow benthic megafauna during an annual cycle in Admiralty Bay, King George Island, Antarctica. Antarct Sci 17:312-318

Gallardo VA (1987) The sublittoral macrofaunal benthos of the Antarctic Shelf. Environ Int 13:71-81

Gambi MC, Lorenti M, Russo GF, Scipione MB (1994) Benthic associations of the shallow hard bottoms off Terra Nova Bay, Ross Sea: zonation, biomass and population structure. Antarct Sci 6:449-462

Gerdes D, Hilbig B, Montiel A (2003) Impact of iceberg scouring on macrobenthic communities in the high-Antarctic Weddell Sea. Polar Biol 26:295-301

Gili JM, Coma R, Orejas C, Lopez-Gonzales PJ, Zabala M (2001) Are Antarctic suspension-feeding communities different from those elsewhere in the world? Polar Biol 24:473-485

Gutt J (1991) Are Weddel Sea holothurians typical representatives of the Antarctic benthos? A comparative study with new results. Meeresforschung 33:312-329

Gutt J (2001) On the direct impact of ice on marine benthic communities, a review. Polar Biol 24:553-564

Jazdzewski K, Sicinski J (1993) Zoobenthos. General remarks. In: Rakusa-Suszczewski S (ed) The Maritime Coastal Ecosystem of Admiralty Bay. Department of Antarctic Biology, Polish Academy of Sciences, Warsaw, pp 83-95

Jazdzewski K, Jurasz W, Kittel W, Presler E, Presler P, Sicinski J (1986) Abundance and biomass estimates of the benthic fauna in Admiralty Bay, King George Island, South Shetland Islands. Polar Biol 6:5-16

Jazdzewski K, Teodorczyk W, Sicinski J, Kontek B (1991) Amphipod crustaceans as an important component of zoobenthos of the shallow Antarctic sublittoral. Hydrobiolgia 223:105-117

Jonasz M (1983) Particulate matter in the Ezcurra Inlet: concentration and size distributions. Oceanologia 15:65-74

Knox GA (1994) The biology of the Southern Ocean. Cambridge University Press, New York

Lipski M (1987) Variations of physical conditions, nutrients and chlorophyll a contents in Admiralty Bay (King George Island, South Shetland Islands, 1979). Pol Polar Res 8:307-332

Marsz A (1983) From surveys of the geomorphology of the shores and bottom of the Ezcurra Inlet. Oceanologia 15:209-220

Mühlenhardt-Siegel U (1988) Some results on quantitative investigations of macroobenthos in the Scotia Arc (Antarctica). Polar Biol 8:241-248
Nakajima Y, Watanabe K, Naito Y (1982) Diving observations of the marine benthos at Syowa Station, Antarctica. Mem Nat Inst Polar Res 23:44-54

Nonato EF, Brito TAS, De Paiva PC, Petti MAV, Corbisier TN (2000) Benthic megafauna of the nearshore zone of Martel Inlet (King George Island, South Shetland Islands, Antarctica): depth zonation and underwater observations. Polar Biol 23:580 588

Numanami H, Hamada E, Naito Y, Taniguchi A (1986) A biomass estimation of epifauna megabenthos by stereophotography around Syowa Station, Antarctica. Mem Natl Inst Polar Res Spec Issue 44:145-150

Pabis K, Sicinski J (2010) Distribution and diversity of polychaetes collected by trawling in Admiralty Bay: an Antarctic glacial fiord. Polar Biol 33:141-151

Palma AT, Poulin E, Silva MG, San Martin RB, Munoz CA, Diaz AD (2007) Antarctic shallow subtidal echinoderms: is the ecological success of broadcasters related to ice disturbance? Polar Biol 30:343-350

Pecherzewski K (1980) Distribution and quantity of suspended matter in Admiralty Bay, King George Island, South Shetland Islands. Pol Polar Res 1:75-82

Peck LS, Brockington S, Vanhove S, Beghyn M (1999) Community recovery following catastrophic iceberg impacts in a softsediment shallow-water site at Signy Island, Antarctica. Mar Ecol Prog Ser 186:1-8

Peck LS, Colman JG, Murray AWA (2000) Growth and tissue mass cycles in the infaunal bivalve Yoldia eightsi at Signy Island, Antarctica. Polar Biol 23:420-428

Piepenburg D, Schmidt MK, Gerdes D (2002) The benthos off King George Island (South Shetland Islands, Antarctica): further evidence for a lack a latitudinal biomass cline in the Southern Ocean. Polar Biol 25:146-158

Propp MV (1970) The study of bottom fauna at Haswell Island by SCUBA diving. In: Holdgate MV (ed) Antarctic ecology vol 1. Academic Press, London, New York, pp 239-241

Rakusa-Suszczewski S (1995) The hydrography of Admiralty Bay and its inlets, coves and lagoons (King George Island, Antarctica). Pol Polar Res 16:61-70

Rehm P, Thatje S, Arntz WE, Brandt A, Heilmayer O (2006) Distribution and composition of macrozoobenthic communities along a Victoria-Land Transect (Ross Sea, Antarctica). Polar Biol 29:782-790

Rhoads DC (1974) Organism-sediment relations on the muddy sea floor. Oceanogr Mar 12:263-300

Saiz-Salinas JI, Ramos A (1999) Biomass size-spectra of macrobenthic assemblages along water depth in Antarctica. Mar Ecol Prog Ser 178:221-227

Saiz-Salinas JI, Ramos A, Garcia FJ, Troncoso JS, San Martin G, Sanz C, Palacin C (1997) Quantitative analysis of macrobenthic soft-bottom assemblages in South Shetland waters (Antarctica). Polar Biol 17:393-400

Saiz-Salinas JI, Ramos A, Munilla T, Rauschert M (1998) Changes in the biomass and dominant feeding mode of benthic assemblages with depth off Livingston Island (Antarctica). Polar Biol 19:424-428

Sicinski J (2004) Polychaetes of Antarctic sublittoral in the proglacial zone (King George Island, South Shetland Islands). Pol Polar Res 25:67-96

Sicinski J, Rozycki O, Kittel W (1996) Zoobenthos and zooplankton of Herve Cove (King George Island, South Shetland Islands, Antarctic). Pol Polar Res 17:221-238

Smale DA, Barnes DKA (2008) Likely response of the Antarctic benthos to climate-related changes in physical disturbance during the 21st century, based primarily on evidence from the West Antarctic Peninsula region. Ecography 31:289-305 
Syvitski JPM, Farrow GE, Atkinson RJA, Moore PG, Andrews J (1989) Baffin Island fjord macrobenthos: bottom communities and environmental significance. Arctic 42:232-247

Szafranski J, Lipski M (1982) Characteristic of water temperature and salinity at Admiralty Bay (King George Island) during austral summer 1978-1979. Pol Polar Res 3:7-24

Tokarczyk R (1986) Annual cycle of chlorophyll $\alpha$ in Admiralty Bay 1981-1982 (King George Island, South Shetland). Pol Arch Hydrobiol 3:177-188

White MG, Robins MW (1972) Biomass estimates from Borge Bay, Signy Island, South Orkney Islands. Br Antarct Surv Bull $31: 45-50$
Wlodarka-Kowalczuk M, Pearson TH (2004) Soft-bottom macrobenthic faunal associations and factors affecting species distribution in an Arctic glacial fjord (Kongsfjord, Spitsbergen). Polar Biol 27:155-167

Wlodarska-Kowalczuk M, Pearson TH, Kendall MA (2005) Benthic response to chronic natural physical disturbance by glacial sedimentation in an Arctic fjord. Mar Ecol Prog Ser 303:31-41 